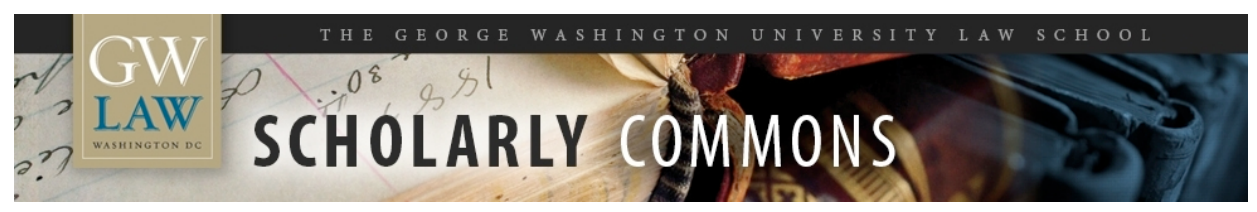

\title{
The European Procurement Directives and The Transatlantic Trade \& Investment Partnership (T-TIP): Advancing U.S. - European Trade and Cooperation in Procurement
}

Christopher R. Yukins

George Washington University Law School, cyukins@law.gwu.edu

Follow this and additional works at: https://scholarship.law.gwu.edu/faculty_publications

Part of the Law Commons

\section{Recommended Citation}

Yukins, Christopher R., The European Procurement Directives and The Transatlantic Trade \& Investment Partnership (T-TIP): Advancing U.S. - European Trade and Cooperation in Procurement (2014). GWU Law School Public Law Research Paper No. 2014-15; GWU Legal Studies Research Paper No. 204-15. Available at SSRN: http://ssrn.com/abstract=2433219 or http://dx.doi.org/10.2139/ssrn.2433219

This Article is brought to you for free and open access by the Faculty Scholarship at Scholarly Commons. It has been accepted for inclusion in GW Law Faculty Publications \& Other Works by an authorized administrator of Scholarly Commons. For more information, please contact spagel@law.gwu.edu. 
THE EUROPEAN PROCUREMENT DIRECTIVES AND THE TRANSATLANTIC TRADE \& INVESTMENT PARTNERSHIP (T-TIP): ADVANCING U.S. - EUROPEAN TRADE AND COOPERATION IN PROCUREMENT

\title{
by
}

\author{
Christopher R. Yukins \\ Lynn David Research Professor in Government Procurement Law \\ Co-Director of the Government Procurement Law Program \\ The George Washington University Law School
}

\section{INTRODUCTION}

Last year's report noted that regulatory efforts on both sides of the Atlantic, in anti-corruption and procurement, are become more interdependent, as the two systems, U.S. and European, evolve in parallel. See Coordinating Compliance and Procurement Rules in a Shrinking World: The Case for a Transatlantic Dialogue, 2013 Gov't Contracts Year in Review Briefs 3 (available on Westlaw). That convergence continued over the past year, as the European Union finalized its new directives on procurement, and the United States and Europe moved forward in negotiating a comprehensive free trade agreement, the Transatlantic Trade and Investment Partnership (T-TIP), which would (among other things) address barriers to trade in procurement.

In Parts II and III, this report will review the T-TIP agreement's potential impact on procurement, in the near and long term. The European T-TIP negotiators are likely to demand greater access to sub-central (state) procurement markets, in return for reducing barriers to European markets, such as in agriculture. In the longer term, the T-TIP negotiations may well lead to a formalized process for addressing regulatory barriers to trade, including - potentially barriers raised by procurement regulations. Part IV will discuss the pending European procurement directives, focusing, especially, on the "classical” procurement directive, rather than on the proposed directives governing concessions or utilities. The discussion below will review some of the more important elements of the draft European procurement directive, will assess whether those elements may have discriminatory impacts on U.S. exporters, and will ask whether those discriminatory effects could be mitigated by better cooperation between regulators on either side of the Atlantic.

\section{THE TRANSATLANTIC TRADE AND INVESTMENT PARTNERSHIP (T-TIP)}

The T-TIP negotiations, launched in early 2013, are intended to result - if successful - in a comprehensive EU-U.S. free trade agreement. E.g., Robin Emmott, EU Trade Chief Hopes to Clinch U.S. Trade Deal by Late 2014, Reuters, Feb. 27, 2013, available at http://uk.reuters.com/article/2013/02/27/us-euro-summit-trade-idUKBRE91Q0QM20130227. Negotiators from the United States hope to eliminate all tariffs on goods sold between the EU and the United States, see U.S. Trade Representative, White House Fact Sheet: Transatlantic Trade and Investment Partnership (T-TIP) (June 2013), available at http://www.ustr.gov/aboutus/press-office/fact-sheets/2013/june/wh-ttip, while European negotiators have made it clear that they hope, through a T-TIP agreement, to gain broader access to U.S. procurement markets, including sub-central (especially state) procurement markets. See, e.g., European Parliament, 


\section{Reproduced with permission of Thomson Reuters.}

All rights reserved.

Legislative Observatory, EU-US Trade Agreement (Sept. 6, 2013), available at www.europarl.europa.eu/oeil/popups/thematicnote.do?id=2052000\&l=en.

The EU-U.S. negotiations may be shaped by a prior trade agreement between Canada and the European Union. In October 2013, Canada and the EU announced that they had reached political agreement on the key elements of a bilateral free trade agreement, the Comprehensive Economic \& Trade Agreement (CETA). See "Atlantic Accord: The Canada-EU Trade Deal," The Economist, Oct. 26, 2013, at 44; European Commission, Trade: Canada, available at http://ec.europa.eu/trade/policy/countries-and-regions/countries/canada/ (Nov. 19, 2013). The CETA agreement (the final terms of which had not been made public as of this writing) would -among a broad range of other trade liberalization measures -- substantially open procurement markets. See, e.g., Government of Canada, Agreement Overview: The Canada-European Union Comprehensive Economic and Trade Agreement, available at http://www.actionplan.gc.ca/en/page/ceta-aecg/agreement-overview\#p3. The CETA agreement is to open all sub-central (including provincial and municipal) levels of government procurement in Canada to European vendors. Furthermore, Canada would, under the agreement, create a single electronic procurement website that would combine information on opportunities at all levels of government, to make it easier for European firms to compete in the Canadian federal, provincial and local procurement markets. See European Commission, Trade: News Archive: Facts and Figures of the EU-Canada Free Trade Deal (Oct. 18, 2013), available at trade.ec.europa.eu/doclib/press/index.cfm?id=974. While the CETA agreement does not include the United States, European officials and others have noted that the Canadian agreement may well serve as a template for the T-TIP agreement. E.g., The Economist, supra, at 44.

With regard to their own potential agreement, the United States and the European Union held several rounds of T-TIP negotiations in 2013, concluding with a third round in December. At the conclusion of the third round, in a joint press conference, the negotiators noted that work on TTIP had progressed, see Live TTIP $3^{\text {rd }}$ Round (Washington 16-20 December) Press Conference, available at http://ec.europa.eu/avservices/video/player.cfm?ref=I084931, and the EU lead negotiator, Garcia Bercero, cited access in procurement as one of the three key goals of the negotiations, id. In early 2014, the two sides were to take political stock of the negotiations, and to plan further rounds of meetings in 2014. Id.

\section{A. Procurement Is Pivotal to the T-TIP Negotiations}

As the negotiations have unfolded, several points of note to the procurement community have emerged. The first is that procurement is politically very important in the T-TIP negotiations, and the European negotiators have made it plain that procurement is a central part of the European Union's negotiating goals. Published reports indicate that the EU would like to be able to point to negotiating success in procurement, to address concerns from stakeholders that a TTIP agreement could grant U.S. exporters much broader access to other sectors, such as agriculture. Ironically, the European Union's own macroeconomic study concluded that opening procurement markets would have a relatively small economic impact - much smaller, say, than eliminating tariffs in the motor vehicle and agricultural sectors. See Centre for Economic Policy Research, Reducing Transatlantic Barriers to Trade and Investment: An Economic Assessment, at 34 (Final Project Report, London, Mar. 2013), available at http://trade.ec.europa.eu/doclib/docs/2013/march/tradoc_150737.pdf. 


\section{B. A Key European Goal in the T-TIP Negotiations Is Access to State Procurement Markets}

In addressing procurement, the European Union's negotiators have made it plain that one key goal is gaining better access to "sub-central" markets, specifically state procurement markets. See, e.g., European Commission, Directorate-General for Trade, Note for the Attention of the Trade Policy Committee of the Council of the European Union re: Transatlantic Trade and Investment Partnership (TTIP) (Doc. 238/13, June 21, 2012), Attachment: EU-US FTA negotiations, Non paper on Public Procurement, at 2 (June 20, 2012) ("The EU proposes that, to the extent possible, the improved rules negotiated bilaterally would apply to the entire scope of the GPA commitments undertaken by both Parties, as well as to additional market access commitments undertaken under the bilateral FTA, at federal as well as at state level.”) [hereinafter "European Commission Non Paper on Public Procurement”], available at http://www.iatp.org/files/TPC-TTIP-non-Papers-for-1st-Round-Negotiatons-June20-2013.pdf.

While integration of the European procurement markets under the EU directives and the WTO Agreement on Government Procurement (GPA) has, in effect, given U.S. exporters broad access to sub-central procurement markets in the European Union, only 37 of the U.S. states have agreed to open their markets under the GPA - and in most cases, those states have opened their procurement markets only partially. See WTO Doc. No. GPA/113, at 417-26 (2012) (text of revised GPA, awaiting ratification, lists states that have agreed to join GPA), available at http://www.wto.org/english/tratop_e/gproc_e/gp_gpa_e.htm. Almost no U.S. cities or other local governments have joined the free trade agreement. Id. at 428 (handful of U.S. local authorities included in GPA).

\section{Most Probable Pathway for European Access to State and Local Markets Is Through Federal Grants}

The U.S. government has long argued that principles of federalism bar the federal government from compelling the states to open their procurement markets under an international agreement, such as the GPA. See generally Amol Mehra, Note \& Comment: Federalism and International Trade: The Intersection of the World Trade Organization's Government Procurement [Agreement] and State “Buy Local” Legislation, 4 B.Y.U. Int'l \& Mgt. Rev. 179 (2008). That delicate relationship between state sovereignty and the federal government's authority, under the Constitution, to negotiate foreign agreements is reflected in the U.S. Code at 19 U.S.C. § 3512, Relationship of agreements to United States law and State law. That statute requires the U.S. Trade Representative to hold regular consultations with the states on matters relating to the Uruguay Round Agreements (including the Agreement on Government Procurement, see http://www.wto.org/english/thewto_e/whatis_e/tif_e/agrm1_e.htm), and describes procedures for the federal government to bring a court action to challenge a state law's nonconformity with the Agreements. While this issue of federalism is not fully settled, see, e.g., Tracey Taylor, The Legislature, The Governor \& International Trade Agreements: An Analysis of Washington Law, at 2 (Office of Program Research, Washington State House of Reps., Dec. 2004), http://www.leg.wa.gov/House/Committees/CDHT/Documents/JLOCTP.pdf, in informal 
discussions members of the European procurement community seem to have accepted the U.S. argument that the federal government may not compel states to open their markets.

As a practical matter, were the remaining states suddenly swept into the GPA, some might fall immediately - and disruptively -- out of apparent compliance with the agreement. For example, while the GPA calls for covered states to have effective and independent bid protest systems, see WTO Doc. No. GPA/113, supra, Art. XVIII, not all states have such bid protest systems in place, see, e.g., National Association of State Purchasing Officers (NASPO), Research Brief: State Bid Protests, available at http://www.naspo.org/documents/.FINAL_NASPO_BidProtests_Research_Brief_042413.pdf.

Binding states to the GPA and other free trade agreements is also politically sensitive: some civil society groups in the United States have loudly opposed efforts to draw states into the GPA and other free trade agreements, arguing that those agreements in effect curb states' ability to further their own social and industrial policies through procurement. See, e.g., Public Citizen, Government Procurement (noting states' efforts to resist joining free trade agreements), available at http://www.citizen.org/trade/subfederal/procurement/.

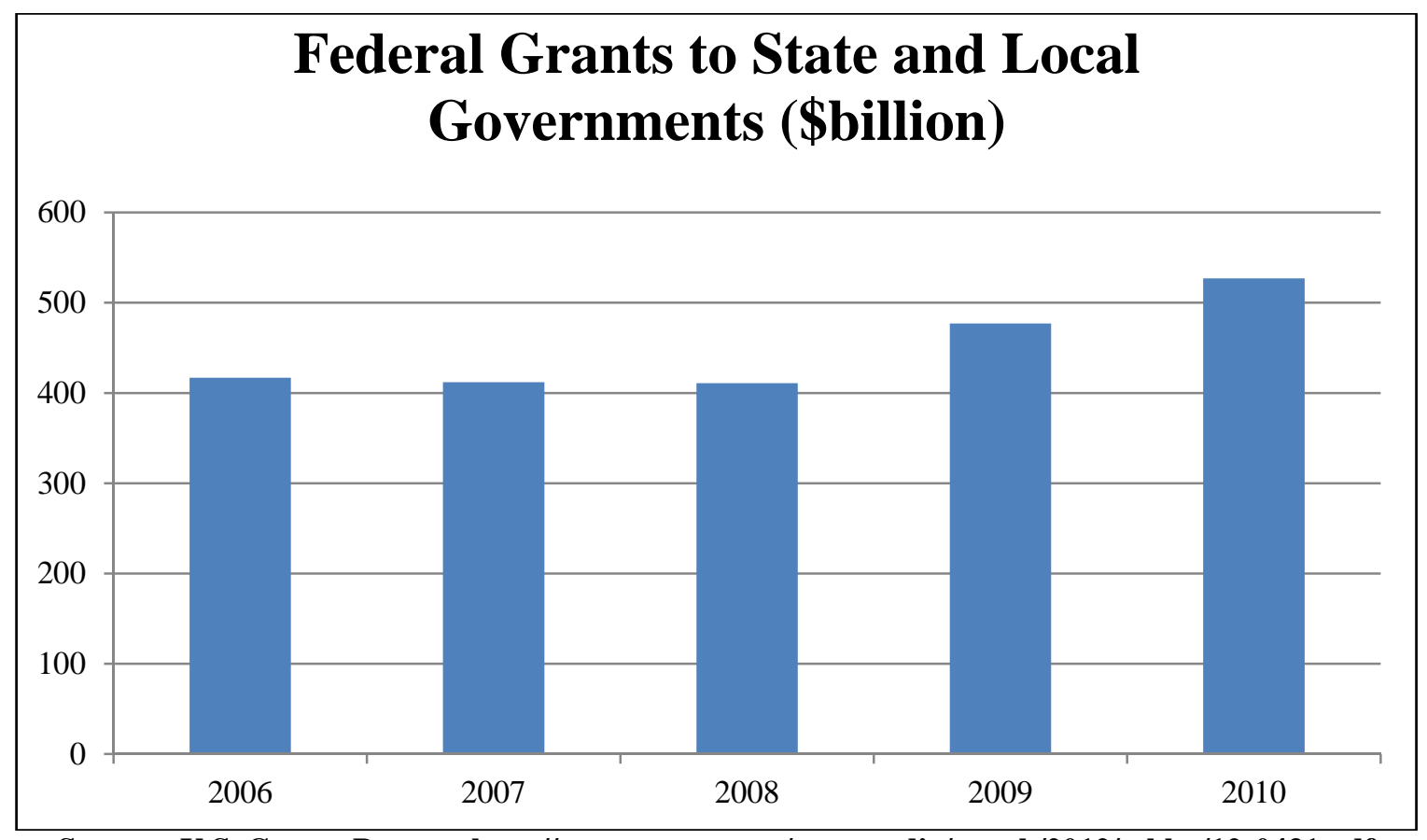

Source: U.S. Census Bureau, http://www.census.gov/compendia/statab/2012/tables/12s0431.pdf

Because of an apparent reluctance to challenge the U.S. government's argument that it may not compel the states to join a free trade agreement, some in the European procurement community have suggested that Europeans could instead gain nondiscriminatory access to state procurement markets indirectly, through the federal government's grantmaking authority. See, e.g., European Commission Non Paper on Public Procurement, supra, at 3 (EU negotiators seek to "[e]nsure committed coverage at federal level extends to cover also federal funding spent at the State level”). These Europeans are arguing, in essence, that the United States should change direction, and use federal grants to liberalize state procurement markets. (In the past, Congress has often 


\section{Reproduced with permission of Thomson Reuters. \\ All rights reserved.}

imposed severe domestic content requirements on state grantees -- for example, Congress tied significant discriminatory domestic preferences to the hundreds of billions of grant dollars that were distributed to state and local governments under the American Recovery and Reinvestment Act, per Section 1605 of that act.) Turning that prior practice on its head, these Europeans argue that the federal government also should be able to tie open market requirements to federal grants.

\section{Grants Rule Traditionally Banned Local and State Preferences; European Suggestion Would Mean Broadening That Prohibition}

The European suggestion -- that state grantees be required to accept foreign competitors when the grantees procure using federal funds -- comes at an interesting time, for (as Steven Schooner and David Berteau note in their accompanying report) the federal grant rules are being overhauled. On February 28, 2012, the U.S. Office of Management \& Budget (OMB), a part of the Executive Office of the President, announced that it was combining the various circulars and guidance which have governed federal grants to states, local governments and other grantees. 77 Fed. Reg. 11,778 (2012). That guidance was issued in final form on December 26, 2013. 78 Fed. Reg. 78,590, http://www.gpo.gov/fdsys/pkg/FR-2013-12-26/pdf/2013-30465.pdf. The goal of OMB's initiative was to streamline federal oversight of grants, while at the same time reducing waste, fraud and abuse in the hundreds of billions of dollars of grants made by the federal government every year. In the T-TIP negotiations, were the United States to accede to European demands that state grantees not discriminate against European vendors, the U.S. commitment might ultimately be included in grants guidance - though, as is discussed below, the final revised grants guidance would need to be changed to expand the bar against procurement preferences.

\section{Federal Grants to State and Local Governments}

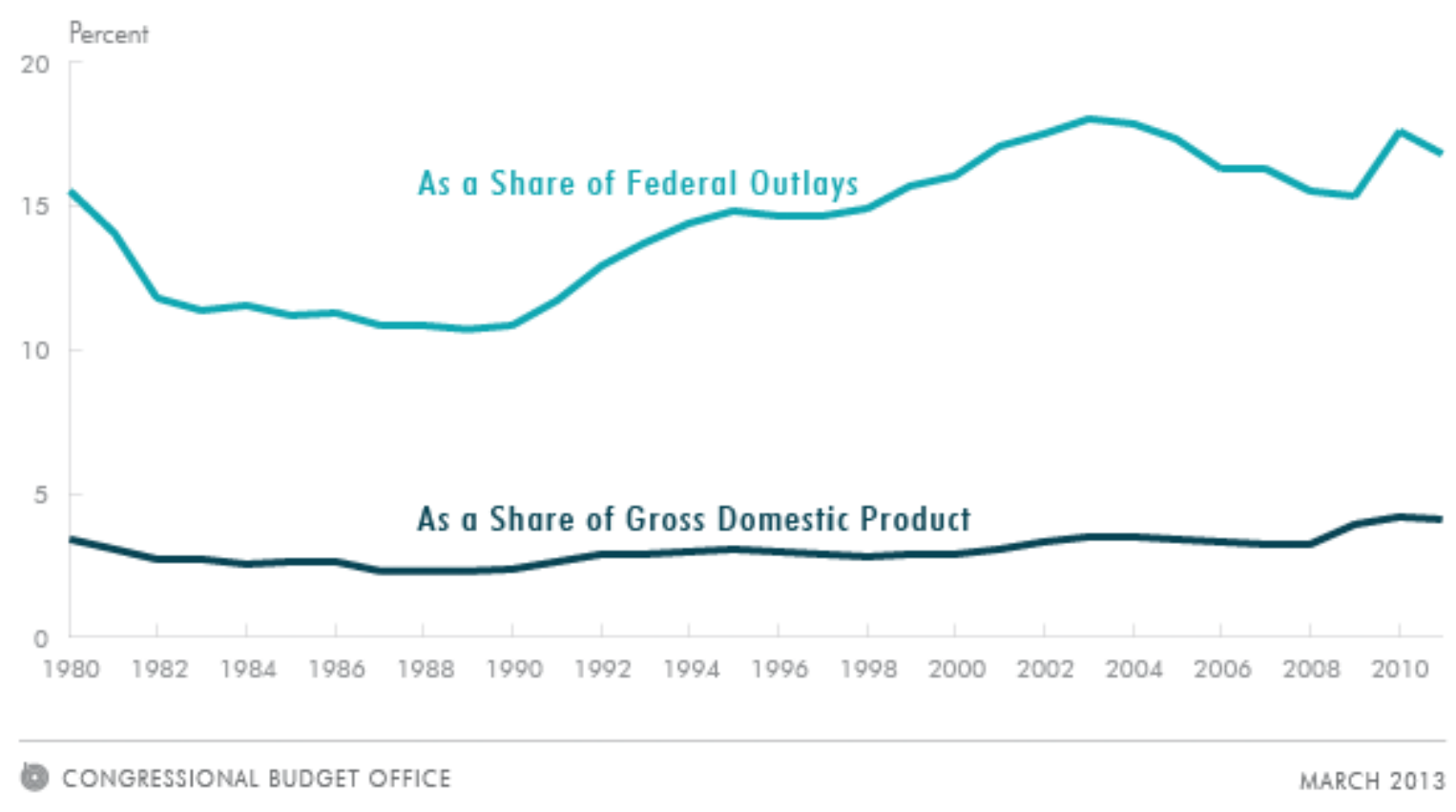

Source: http://www.cbo.gov/publication/43967 


\section{Reproduced with permission of Thomson Reuters.}

All rights reserved.

For over two decades, the common rule which governed federal grants to state and local governments barred grantees from discriminating based on state or local procurement preferences, see 53 Fed. Reg. 8034, 8097 (1988) (common rule $\S \_.36(c)(2)$ ), though this rule apparently did not apply to the states themselves, see 53 Fed. Reg. at 8096 (1988 common rule $\S \_.36(\mathrm{a})$ deferred to state procurement standards)). Even when OMB procurement standards for state grantees (discussed below) were largely abolished during a previous round of major reform (during the Reagan administration), to be replaced by the grants management common rule in 1988, see Office of Management \& Budget, Grants Management, Grants Circular Attachments, http://www.whitehouse.gov/omb/grants_attach, the new common rule nevertheless banned state and local procurement preferences. See 53 Fed. Reg.. at 8039 ("The application of unreasonably restrictive qualifications and any percentage factors that give bidding advantages to in-State or local firms are barriers to open and free competition which are not in the public interest. Section _..36(c)(2) [of the common rule] was included in the proposed regulation to foster competition, fairness, and economy in the award of contracts.”).

While the various federal departments and agencies adapted the common rule in different ways over the years, see http://www.whitehouse.gov/omb/grants_attach/ (compendium of implementing regulations); David J. Cantelme, Federal Grant Programs to State and Local Governments, 25 Pub. Cont. L.J. 335 (1996), the U.S. Department of Defense and the U.S. Department of Health \& Human Services (HHS), among other agencies, consistently included the common rule's ban against state and local preferences in grantee procurement, in their versions of the common rule. See 32 C.F.R. § 33.36(c)(2) (Defense Department grants rule); 45 C.F.R. § 92.36(c)(2) (HHS grants rule); 53 Fed. Reg. 8034, 8097 (1988) (text of common rule: "Grantees and subgrantees will conduct procurements in a manner that prohibits the use of statutorily or administratively imposed in-State or local geographical preferences in the evaluation of bids or proposals, except in those cases where applicable Federal statutes expressly mandate or encourage geographic preference.”).

Those rules were reformed in the last days of 2013, when OMB published revamped guidance on grants, including changes to the grants management common rule. 78 Fed. Reg. 78,590 (Dec. 26, 2013), http://www.gpo.gov/fdsys/pkg/FR-2013-12-26/pdf/2013-30465.pdf. As with the previous OMB circulars and the common rule, the revised guidance sets limited procurement standards (discussed below), 78 Fed. Reg. at 78,631-334 (§§ 200.317-326), and section 200.319, the procurement standard which bars state and local procurement preferences, still apparently does not apply to states. See 78 Fed. Reg. at 78,631 (§ 200.317) ("When procuring property and services under a Federal award, a state must follow the same policies and procedures it uses for procurements from its non-Federal funds. The state will comply with $\S 200.322$ Procurement of recovered materials and ensure that every purchase order or other contract includes any clauses required by section $\& 200.326$ Contract provisions. All other non-Federal entities, including subrecipients of a state, will follow $\$ \S 200.318$ General procurement standards through 200.326 Contract provisions.” (emphasis added)). New section 200.319(b) - which, as noted, apparently does not apply to procurement by a state itself -- now reads, in relevant part:

The non-Federal entity must conduct procurements in a manner that prohibits the use of statutorily or administratively imposed state or local geographical preferences in the 


\section{Reproduced with permission of Thomson Reuters.}

All rights reserved.

evaluation of bids or proposals, except in those cases where applicable Federal statutes expressly mandate or encourage geographic preference.

78 Fed. Reg. at 78,631. The Office of Management and Budget seems, therefore, to have continued the decades-old bar which prevented grantees (but not states) from applying state and local preferences when they procured using federal grant funds.

Thus, were the European T-TIP negotiators successful in persuading the United States to require that state grantees afford European vendors "national treatment” (i.e., treat European vendors as they would treat U.S. vendors) when procuring with federal grant funds, that U.S. concession would, it seems, mean (a) confirming the text of the revised grants guidance, which as noted bans in-state or local preferences in grantee procurements (other than by the states themselves), except where required by federal statute; (b) broadening the ban to include states, as grantees engaged in procurement, to bar them from applying in-state or local preferences against European vendors, except where required by federal law (on the assumption that these federally mandated preferences are already appropriately excepted from any relevant free trade agreement); and, (c) broadening the ban, to prohibit states from applying national preferences (e..g., "Buy American” preferences) against European vendors, except where required by federal law.

\section{E. Requiring State Grantees to Open Their Procurement Markets To European Firms Under T-TIP May Mean Again Imposing Comprehensive Procurement Standards}

A simple commitment to ensure national treatment in procurement under federal grants may not be enough, however. Experience has shown that free trade agreements in procurement must also address non-tariff barriers to trade; in other words, it is not enough to treat foreign vendors without discrimination, if there are other procurement rules or processes (non-tariff barriers to trade) which in practice impede those foreign vendors. To address this second layer of trade barriers, the Europeans may insist that the U.S. government also require state (and presumably other) grantees to follow certain procedural standards in procurement. The negotiators could agree, for example, to require grantees to follow the minimum requirements of the GPA holding solicitations open for a minimum number of days, for example, and establishing independent bid protest systems, see WTO Doc. No. GPA/113, supra (procedural requirements under pending version of the GPA).

Notably, as was suggested above, there is precedent for requiring grantees to follow comprehensive procurement standards, when the grantees procure using federal funds. OMB Circular A-110, recently incorporated into the revamped grants guidance (see above), has long required that universities and other non-profit grantees use procurement systems which meet certain comprehensive standards, see http://www.whitehouse.gov/omb/circulars_a110, and historically OMB Circular A-102 (which applied to state and local government grantees) also imposed more limited requirements for procurement. In fact, until the Reagan administration abolished Circular A-102’s more expansive standards, see, e.g., 53 Fed. Reg. 8034, 8035 (1987) ("Consistent with the President's Federalism Executive Order, the proposed common rule provided that in three important areas [including] . . . procurement ... States will expend and account for grant funds according to their own laws and procedures.”), state and local 


\section{Reproduced with permission of Thomson Reuters.}

All rights reserved.

governments which received federal grants were required to meet relatively comprehensive procurement standards.

Those comprehensive standards governing state and local grantees evolved over the years; in 1977, for example, OMB Circular A-102, Attachment O, required grantees, among other things, to:

- Institute a code of conduct;

- Make maximum use of open and free competition, with an eye to organizational conflicts of interest and non-competitive practices;

- Undertake prior review to ensure that duplicative items were not procured;

- Ensure that technical requirements were clearly and accurately stated, and that "brand name or equal” requirements clearly state the specific features which must be met;

- Utilize small and minority-owned businesses, to allow those sources "the maximum feasible opportunity to compete for contracts to be performed under Federal grant funds";

- Use appropriate procurement methods, and not "cost-plus-a-percentage-of-cost” methods;

- Use formal advertising and public bid openings;

- Use negotiated procurement only when it was "impracticable and unfeasible" to use formal advertising, and even then to ensure competition "to the maximum extent practicable";

- Limit awards to responsible contractors only, considering such elements as contractor integrity, past performance, financial and technical resources; and access to other necessary resources;

- Document important decisions in the procurement process;

- Maintain a system of contract administration; and,

- Include contractual provisions:

o For termination for convenience and for default;

o Affording the Comptroller General audit access; and,

o Requiring compliance with the Clean Water Act.

42 Fed. Reg. 45,889-91 (Sept. 12, 1977) (Attachment O to Circular A-102, Procurement Standards).

The earlier OMB guidance thus set comprehensive requirements for an effective procurement system for state and local government grantees, although the guidance did not reflect all of the elements (such as a bid protest system) required by the current GPA. In the years before the Circular A-102 procurement standards were materially narrowed near the end of the Reagan administration, some local grantees met these comprehensive procurement requirements by adopting an abbreviated version (called an “ordinance”) of the American Bar Association's Model Procurement Code. See, e.g., 47 Fed. Reg. 8960 (1982) (“working in conjunction with the American Bar Association (ABA), EPA has been developing a Model Procurement Ordinance for small communities which is based upon the ABA Model Procurement Code for State and Local Governments”); http://www.americanbar.org/content/dam/aba/administrative/public_contract_law/1982MP_Ord. authcheckdam.pdf (text of ordinance). 


\section{Reproduced with permission of Thomson Reuters.}

All rights reserved.

As recently revised, however, the OMB grants guidance does not impose comprehensive procurement standards on state grantees. Per the discussion above, while the revised grants guidance issued on December 26, 2013 includes procurement standards for grantees (other than states), those requirements are much more limited than they were, say, in 1977, and for the most part those more limited standards apparently do not apply to the states themselves (when the states procure using federal grant funds). See $\S 200.317,78$ Fed. Reg. at 78,631. Thus, if robust procurement standards are to apply to the states and other grantees - if the United States is to address European concerns about trade barriers by imposing uniform and comprehensive procurement standards on states and other grantees when they procure using federal dollars - the revised grants guidance will have to be rewritten to once again extend those comprehensive procurement standards (including, presumably, the bar against state and local preferences discussed above) to states and other grantees.

\section{F. Potential Impacts of T-TIP Agreement on Opening Sub-Central Markets}

The European Union's initiatives to open state procurement markets could have significant impacts, in many different quarters. For example, affording European vendors equal access to state procurement markets could increase competition and enhance best value in state purchasing, but could also increase compliance burdens for state procurement officials, and could make it more difficult to use procurement to carry out state development policies. Taking the next step, and addressing non-tariff barriers to trade by requiring state government grantees to adopt uniform procurement standards (as the federal government did in the past), could both enhance competition and increase compliance costs, as states and other affected grantees struggled to bring their procurement systems to the federal standards. In the long term, however, by increasing uniformity this reform could increase competition, transparency, integrity and the flow of commerce across many thousands of state and local procurement systems in the United States - which are, ironically, the same goals that the Europeans have pursued, in implementing their own uniform procurement directives (discussed below).

\section{T-TIP Agreement: Long-Term Regulatory Cooperation in Procurement?}

The discussion above focused on how the United States might accommodate Europeans' demand that European exporters be given the same access to sub-central procurement markets which U.S. exporters enjoy in Europe - how, in other words, a T-TIP agreement could be used to give Europeans vertical access into the U.S. state procurement markets. A separate issue, however, is whether the United States and the European Union might erect a long-term structure for coordinating federal and European Union procurement rules, to facilitate transatlantic trade in the procurement markets.

While those involved have argued for using the T-TIP agreement to establish a long-term mechanism for cooperating on laws and regulations that may raise non-tariff barriers to trade, see, e.g., http://trade.ec.europa.eu/doclib/docs/2013/july/tradoc_151622.pdf, procurement regulation has generally not been part of that discussion. The European negotiators have instead indicated that the T-TIP agreement would be used to frame future cooperation in other spheres of regulation, aside from procurement. Those other areas of potential cooperation apparently grow, in part, out of ongoing discussions within the World Trade Organization (WTO), to reduce technical barriers to trade (TBTs). 


\section{Reproduced with permission of Thomson Reuters.}

All rights reserved.

Procurement need not, however, be left behind. There is, after all, a common expectation that a T-TIP agreement could result in far less discriminatory procurement rules on both sides of the Atlantic, see, e.g., Business Coalition for Transatlantic Trade, Procurement, http://www.transatlantictrade.org/issues/procurement/, and while negotiators have focused on future coordination in other spheres of regulation, this gap in the negotiations seems both unfortunate and unnecessary, for several reasons.

First, the shared economic benefits of coordinating regulatory regimes - a cornerstone to the TTIP negotiations - are well-recognized. As one study sponsored by the European Union noted:

Focusing efforts on reducing NTBs [non-tariff barriers to trade] is critical to the logic of transatlantic trade liberalization. Different approaches to the same regulatory challenges have the unintended consequence of increasing costs for firms, which have to comply with two regulatory environments, dragging down labour productivity. Negotiation on NTBs provides the opportunity to pursue a mix of cross-recognition and regulatory convergence to reduce these barriers. Compared to a focus on NTBS, just limiting the exercise to tariffs would lead to much more limited, though positive effects.

Centre for Economic Policy Research, supra, at 3.

Second, although the EU and the United States have launched a Bilateral Investment Forum in the wake of the revised GPA, see U.S. Trade Representative, Benefits for the United States from the Revised WTO Government Procurement Agreement, http://www.ustr.gov/about-us/pressoffice/fact-sheets/2011/december/benefits-united-states-revised-wto-government-procur, the scope and agenda of past exchanges on procurement suggest that because those exchanges occur between agencies focused on international trade, not procurement, the exchanges tend to be focused on trade barriers, not harmonization.

Finally, coordination on procurement matters is relatively easy - procurement regulators on both sides of the Atlantic almost always speak the same language (both figuratively and literally), the official rule-writing systems in Washington and Brussels are mature, sophisticated, and inclusive, and stakeholders in both capitals are involved and deeply invested in harmonization. And as the discussion below reflects, the current round of reform in the European procurement directives could have benefitted materially from better communications across the Atlantic with better cooperation between the two procurement regimes, both bodies of regulation (U.S. and European) could be improved.

\section{REFORM OF THE “CLASSICAL” EUROPEAN PROCUREMENT DIRECTIVE: AN AMERICAN PERSPECTIVE ON POTENTIAL POINTS OF DISCRIMINATION AND COOPERATION}

To ensure that procurement is integrated within the rest of the European economy, the European Union issues directives covering procurement by governments, utilities and related entities within the European Union. See, e.g., Sue Arrowsmith, "The Purpose of the EU Procurement Directives: Ends, Means and the Implications for National Regulatory Space for Commercial and Horizontal Procurement Policies," in C. Barnard, M. Gehring and I. Solanke (eds.), Cambridge 
Yearbook of European Legal Studies (Hart Publishing, Oxford, 2011-2012), Vol. 14, pp. 1-48; Pedro Telles, The Good, The Bad, and the Ugly: The EU's Internal Market, Public Procurement Thresholds, and Cross-Border Interest, 43 Pub. Cont. L.J. 3 (2013). The directives - and we will focus here on the latest available (July 12, 2013) compromise text of the proposed directive governing traditional (“classical”) procurement by public entities, available at http://publicsector.practicallaw.com/blog/publicsector/plc/?p=1550 - are currently being revamped, once again. While the current reforms are extensive, the discussion below will address a few provisions from the proposed "classical” directive, to show how they might be used to discriminate against U.S. exporters and how, with richer communications between Washington and Brussels, the directive's provisions (and federal procurement regulation) might be improved in future rounds of reform.

\section{A. Defense Procurement: Covered by New Directive or Not?}

With the drop in U.S. defense spending, the new European directive's coverage of defense procurement is an important issue to the U.S. defense community. While the proposed directive's Article 14 explicitly states that the proposed directive "shall apply to the awarding of public contracts and to design contests organised in the fields of defence and security," the proposed directive exempts those contracts to which the European defense procurement directive (Directive 2009/81/EC) does apply, and then - in an even more curious twist - also exempts those contracts to which the defense directive does not apply.

One way to make sense of this apparently odd scheme is to assume that the European regulators intend to bring the least sensitive defense procurements within the new "classical" directive, to leave moderately sensitive defense procurements within the 2009 defense directive, and to exempt entirely the most sensitive procurements. The following diagram suggests a conceptual model for this regulatory structure.

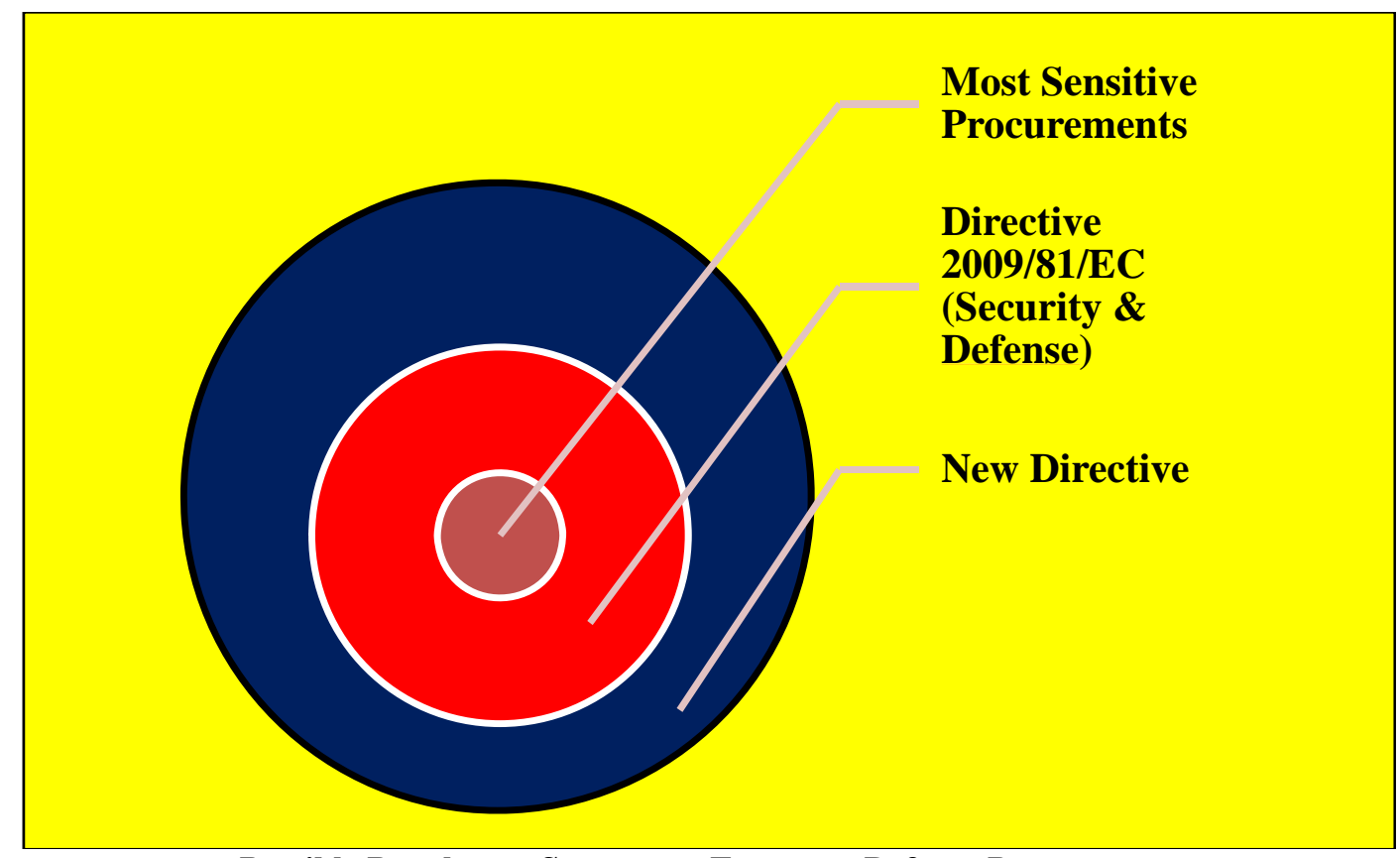

Possible Regulatory Structure - European Defense Procurement 


\section{Reproduced with permission of Thomson Reuters.}

All rights reserved.

The 2009 defense procurement directive contains a number of anomalous provisions, see generally Christopher R. Yukins, Feature Comment: The European Defense Procurement Directive: An American Perspective, 51 GC 9383 (Nov. 4, 2009), which do not appear in the proposed "classical" directive, and so determining which directive applies could have a material impact on a procurement. For example, while the defense directive seeks to curb the use of offsets, see, e.g., Katharina Weiner, Towards European Preferences? Implications of Directive 2009/81/EC on Domestic Preferences in Defense Procurement, 47 Proc. Law. 16 (ABA Spring 2012), the proposed "classical" directive is silent on offsets. Where a procurement award is likely to be affected by rich offers of offsets - and offsets have long been an important factors in European defense awards, see, e.g., Jeffrey P. Bialos, Christine E. Fisher \& Stuart L. Koehl, The Evolution of the Transatlantic Defense Market and the Implications for U.S. National Security Policy, vol. 1, at 19 (2009), available at http://www.acq.osd.mil/mibp/docs/fortresses_and_icebergs_vol-one.pdf; Mark J. Nackman, A Critical Examination of Offsets in International Defense Procurements: Policy Options for the United States, 40 Pub. Cont. L.J. 511 (2011) - there may be a good deal of jostling to bring a new defense procurement in, or out, of the new directive. Because the other mechanisms for coordinating defense procurement policy with the United States' European allies remain somewhat fragmented, see, e.g., Drew B. Miller, Note: Is It Time to Reform Reciprocal Defense Procurement Agreements?, 39 Pub. Cont. L.J. 93 (2009), resolving this uncertainty of coverage could have been a productive point of discussion between Washington and Brussels, while the new directive was being framed.

\section{B. Exclusion of Contractors (Debarment): A Patchwork of Uncertainty}

The proposed directive also opens a hornets' nest of potential problems regarding exclusion of contractors (what in the U.S. system is called "contractor non-responsibility" and "suspension and debarment"). Although federal debarment officials retain broad discretion to exclude contractors under Federal Acquisition Regulation Part 9, and the system is far from perfect, see, e.g., House Oversight Committee Passes Suspension and Debarment Overhaul, 55 GC \ 351 (Nov. 6, 2013), contractors in the U.S. market know that they can (and should) negotiate directly with debarment officials, to head off exclusion by bolstering internal compliance systems and taking other remedial measures.

The risks of exclusion are much less predictable, however, under the proposed European directive. The recitals to the directive, speaking to proposed Article 55, indicate that contractors must be excluded, on a mandatory basis, for participation in a "criminal organisation" (not defined), for being guilty of "corruption" (again, undefined), "fraud to the detriment of the Union's financial interests" (a surprisingly narrow ambit for fraud), terrorist offenses, and nonpayment of taxes or social security contributions. On a non-mandatory basis, contracting officials may also exclude prospective contractors for any "misbehaviour that casts serious doubts as to the reliability of the economic operator." The next recital (44) leaves open the possibility of rehabilitation, based on contractor remedial measures, but leaves it to the individual member states to decide how, and whether, to exclude. In sum, the proposed directive opens a host of potential grounds for exclusion, but leaves the substantive and procedural rules 


\section{Reproduced with permission of Thomson Reuters.}

All rights reserved.

for exclusion (and rehabilitation) very vague. This, in turn, opens very real risks that vendors may be arbitrarily excluded, or even that contracting officials might try to leverage their discretion by seeking bribes from contractors tainted by bad acts or poor performance.

In this area, again, communication between Washington and Brussels would be useful. There are several different models of debarment emerging around the world: a highly discretionary model, with rigorous but informal procedures, focused first on issues of performance risk (e.g., the United States); a more structured and adjudicative approach, focused on issues of fiduciary loss ("leakage" through corruption) and reputational risk (e.g., the World Bank sanctions process), see, e.g., Christopher R. Yukins, Rethinking the World Bank's Sanctions System, 55 GC I 355 (Nov. 2013), available at http://ssrn.com/abstract=2357691; and, the European approach, which remains a somewhat uneven hybrid of the discretionary and the compulsory, with only loosely described procedures, $c f$., e.g., Hermann Pünder, Hans-Joachim Priess \& Sue Arrowsmith (eds.), Self-Cleaning in Public Procurement Law (Carl Heymanns, 2009). Discussions between officials in the various procurement communities - especially, discussions including debarment officials and their stakeholders - would be a very useful way to harmonize sanctions systems, and so to regularize the incentives and deterrents regarding fraud, corruption and poor performance.

\section{Harmonizing Multilateral Negotiations Procedures with Offerors}

The new directive also reflects European regulators' slow - but now more open - embrace of competitive negotiations, such as those allowed by Part 15 of the Federal Acquisition Regulation. Recital (15) to the proposed directive reflects the European regulators' growing enthusiasm for multilateral, competitive negotiations (as opposed to sealed bidding ("open tendering”), which was traditionally the favored method):

There is a great need for contracting authorities to have additional flexibility to choose a procurement procedure, which provides for negotiations. A greater use of these procedures is also likely to increase cross-border trade, as the evaluation has shown that contracts awarded by negotiated procedure with prior publication have a particularly high success rate of cross-border tenders. Member States should be able to provide for the use of the competitive procedure with negotiation or the competitive dialogue, in various situations where open or restricted procedures without negotiations are not likely to lead to satisfactory procurement outcomes.

Cf. Chris Browne, Best Practice Group, Ltd., Changes to EU Procurement Rules: Innovation Partnerships, Preliminary Market Consultations \& Joint Procurements (Sept. 4, 2013) ("Historically, [in Europe] the vast majority of pre-competition engagement has included very little dialogue between parties, mainly due to the understandably cautious approach of Authorities facing a lack of historical guidelines on just how much, if any, dialogue with the market is allowed before issuing tenders.”), available at http://www.bestpracticegroup.com/euprocurement-rules-innovation-partnerships-pmc/. While the 2004 European "classical” directive allowed only "competitive dialogue," the proposed new directive would now also recognize "competitive procedure with negotiation"; as the following chart shows, this new procedure appears to be much closer to competitive negotiations, per the U.S. federal model: 


\begin{tabular}{|c|c|c|}
\hline $\begin{array}{l}\text { KEY } \\
\text { ELEMENTS }\end{array}$ & $\begin{array}{l}\text { Competitive Procedure with } \\
\text { Negotiation - Art. } 27 \text { (new) }\end{array}$ & $\begin{array}{l}\text { Competitive Dialogue - Art. } 28 \\
\text { (allowed since } 2004 \text { directive) }\end{array}$ \\
\hline $\begin{array}{l}\text { Who May Submit } \\
\text { Initially }\end{array}$ & $\begin{array}{l}\text { Any vendor may respond to } \\
\text { request for information re: } \\
\text { minimum requirements. }\end{array}$ & $\begin{array}{l}\text { Any vendor may submit request to } \\
\text { participate in response to notice. }\end{array}$ \\
\hline Next round & $\begin{array}{l}\text { Those invited may submit } \\
\text { tender for negotiations. }\end{array}$ & $\begin{array}{l}\text { Those invited may participate in } \\
\text { dialogue. }\end{array}$ \\
\hline $\begin{array}{l}\text { Exchanges with } \\
\text { vendors }\end{array}$ & $\begin{array}{l}\text { Negotiation of anything but } \\
\text { min. reqts. and award criteria }\end{array}$ & $\begin{array}{l}\text { Authority opens dialogue with selected } \\
\text { participants, to identify best means of } \\
\text { satisfying needs. }\end{array}$ \\
\hline Award on initial? & Yes, if warned. & \\
\hline Equal treatment & $\begin{array}{l}\text { Specifications may change, with } \\
\text { notice. Equal treatment } \\
\text { required. }\end{array}$ & $\begin{array}{l}\text { No sharing of confidential information, } \\
\text { unless specifically agreed. }\end{array}$ \\
\hline Limit bidders? & $\begin{array}{l}\text { May limit number; may reduce } \\
\text { through stages. }\end{array}$ & $\begin{array}{l}\text { Competitive dialogues may occur in } \\
\text { stages, to reduce number of solutions, } \\
\text { if notice. }\end{array}$ \\
\hline Final offers? & On notice. & $\begin{array}{l}\text { Dialogue to continue until authority } \\
\text { identifies solution(s) needed. Final } \\
\text { tenders then requested. Tenders may } \\
\text { be clarified; no change to essential } \\
\text { aspects of tenders or procurement if } \\
\text { likely to distort competition or have } \\
\text { discriminatory effect. }\end{array}$ \\
\hline $\begin{array}{l}\text { Prizes or } \\
\text { Payments }\end{array}$ & & Authority may specify. \\
\hline
\end{tabular}

Here, ongoing cooperation between authorities in Brussels and Washington would be useful, in part so that the European regulators can take advantage of the U.S. government's long experience with competitive negotiations and - equally importantly - so that the competitive procedures can be harmonized between the United States and Europe, to the extent appropriate. Differences in regulated procedures themselves work an artificial barrier to trade, if vendors must learn new procedures when they enter a new market. While there may be sound differences between different competitive procedures, where those differences are not based on necessity where the differences are simply products of different regulatory histories, for example - they should, if possible, be smoothed away, to enhance competition in global procurement markets. 


\section{Reproduced with permission of Thomson Reuters.}

All rights reserved.

\section{Material Changes to Contracts - An Argument for Judicial Coordination}

Coordination between the two systems should not, it must be emphasized, be limited to regulators. Courts also play pivotal roles in shaping procurement rules, as the proposed directive points up. Article 72 of the proposed directive includes a new provision on material changes to contracts - what U.S. courts have traditionally called "cardinal” changes. The new article erects a somewhat formalistic structure around a very economically based decision of the Court of Justice of the European Union: when new requirements introduce new conditions which would, at the original competition, have brought other vendors into the competition, the new requirements are material, and should trigger a new competition. See Case No. C454/06, Pressetext Nachrichtenagentur GmbH v. Rupublik Österreich, 2008 E.C. R. I-4401 (“An amendment to a public contract during its currency may be regarded as being material when it introduces conditions which, had they been part of the initial award procedure, would have allowed for the admission of tenderers other than those initially admitted.”); Gabriella M. Racca, Roberto Cavallo Perin \& Gian Luigi Albano, Competition in the Execution Phase of Public Procurement, 41 Pub. Cont. L.J. 89 (2011); Adrian Brown, When Do Changes to an Existing Public Contract Amount to the Award of a New Contract for the Purposes of the EU Procurement Rules? Guidance at Last in Pressetext Nachrichtenagentur GmbH (Case C454/06), 17 Pub. Proc. L. Rev. NA253, NA 255 (2008).

The Court of Justice's holding in Pressetext, grounded in competitive considerations, is in fact very similar to the "cardinal change” rule long applied by U.S. courts and the Government Accountability Office: when new requirements could have "changed the field" of the original competition, there has been a "cardinal change" to the original contract and so a new competition is in order. E.g., Lasmer Indus., Inc., Comp. Gen. B-401046 et al., 2009 CPD 977 (2009). The Pressetext holding was sound, but there is no evidence that the European court at any point consulted U.S. precedent - it seems that the Court of Justice reached the same rule by logic, and by carefully weighing the economic and administrative forces that naturally work through a procurement system. In the future, however, it may be worthwhile if the European courts develop a reliable means to consult their U.S. counterparts, as the European and U.S. procurement regimes continue to evolve in parallel.

\section{CONCLUSION}

Procurement systems in Europe and the United States are growing ever more closely engaged. The European Union and the United States have launched broad negotiations to create a free trade area, under a new transatlantic trade agreement (the Transatlantic Trade \& Investment Parnership (T-TIP)). In part because of special dynamics within those negotiations, procurement has emerged as a critical issue - specifically, access by European vendors to state procurement markets in the United States. Because the federal government insists that it cannot, for reasons of federalism, afford that access directly, the Europeans have suggested that they can gain substantial access if the federal government ensures that state governments, when using federal grant monies, do not discriminate against European vendors. In fact, federal grants guidance already bars certain grantees from recognizing state and local preferences in procurement, and so the European request - to require state grantees to afford European vendors "national treatment" - may require only incremental changes, to bar local, state and national preferences in state procurements under federal grants. The T-TIP negotiations also may lead to long-term 
cooperation between Brussels and Washington on regulatory matters - including, potentially, cooperation on procurement regulation. As the examples discussed above from the new European procurement directive show, ongoing cooperation between the two capitals could make both the European and the U.S. procurement systems stronger and more competitive. 